\title{
Research Directions in Information Systems Field, Current Status and Future Trends: A literature analysis of AIS Basket of Top Journals
}

\author{
Elham Mazaheri \\ Department of Management, \\ Faculty of Economics and Administrative Sciences, \\ Ferdowsi University of Mashhad, \\ Mashhad, Iran. \\ e.mazaheri@mail.um.ac.ir
}

\section{Mohammad Lagzian}

Department of Management,

Faculty of Economics and Administrative Sciences,

Ferdowsi University of Mashhad,

Mashhad, Iran.

\section{Zahra Hemmat}

Department of Management,

Faculty of Economics and Administrative Sciences,

Ferdowsi University of Mashhad,

Mashhad, Iran.

\section{Abstract}

Information system, as an emerging discipline which is dynamic and interdisciplinary, is constantly undergoing rapid changes; therefore, one of the most critical issues is to study the topics and methodological trends in this field. This study aimed to thoroughly investigate the topics and methodologies used in information system throughout a twelve-year period (20072018). In the present study, all the articles published in the top eight information system journals were investigated based on their topics and methodologies using a literature analysis approach, and the most common topics and methodologies in such studies were then detected. The main topics addressed in this field were electronic commerce/business, information system research, and IS usage/adoption, and the survey was the dominant research methodology in this regard. Furthermore, an increase in the use of the mathematical models indicates that more accurate quantitative research methods have made this field more mature. The research findings also show that the Internet of Things (IoT), big data, social media, bitcoin and block chain, digital transformation, sharing economy, digital platform, methodology of machine learning, data mining, and text mining are the main research topics and methods which should be further studied.

Keywords: Information Systems Research; Research Methodology; Literature analysis; Association for Information Systems; Senior Scholars' Basket of Journals; Academic Journals

\section{Introduction}

Compared to many disciplines in the field of social sciences and business, information system is a relatively new, emerging, and unique field undergoing constant changes for several reasons. On one hand, the changes in information technology, as one of the main areas of 
information system research, are occurring so quickly that researchers can hardly address a particular phenomenon or topic in-depth before dealing with the other new issues since the speed of technological advances in software technology and the other information and communication technologies such as social media, smart devices, and new delivery mechanisms is extremely high. Another reason for the changes in this field is the emergence of new research paradigms, including interpretive and critical research, and new methodologies such as design science, action research and other methods, which have been extensively accepted. Furthermore, new researchers with different backgrounds and experiences have been involved in this field. In addition, these researchers deal with a variety of theories, theoretical foundations, frameworks, and reference disciplines (namely management, organization sciences, and computer sciences). Accordingly, the dynamic and interdisciplinary nature of the information system field and its diversity and rapid advances make it difficult for researchers to keep track of the modern-of-art topics and methodology trends; hence, having information about the current status of research in this filed and being aware of its change processes would help the researchers in the field of information systems.

The present study investigated topics and methodology trends of research in the field of information systems throughout a 12-year period (2007-2018) using a literature analysis method. According to Stemler (2001), the literature analysis enables researchers to study and navigate large knowledge bases using relatively simple and systematic methods. In this study, the data was gathered based on the review of eight major journals in the field of information systems as such a large database including 3250 articles was created. The collected data encompassed the journal name, the year of publication of a concerned article, and the topic and methodology of the research paper.

An in-depth review of previous studies reveals that no comprehensive analysis has been carried out in recent years, and the most recent comprehensive research has been conducted during 2004-2013. Furthermore, some of the most recent studies have concentrated on only one journal (Palvia \& Kakhki, 2016; Palvia et al., 2017). As a result, there are few comprehensive studies in this field. Considering the significance of this subject, the present study analysed the topics and methodologies used in the AIS Basket of the top journals throughout a twelve-year period (2007-2018). This review study would contribute to the improvement of the research on information systems. The main objectives of this study are as follows:

1. Determining the topics addressed by the researchers and analysing the research trends;

2. Detecting the most common research methodologies and their trends;

3. Identifying research gaps and predicting the future trends of information system research.

In the following, a review of the relevant literature is presented. In addition to the research methodology, the frameworks used to analyse the articles along with the journal selection procedures and the coding methods are also described. Furthermore, the analysis and coding results are also discussed. This paper also encompasses topic and methodological trends and is concluded with some discussions along with limitations and recommendations for future research. 


\section{Literature review}

Since the early emergence of information systems, some researchers have published studies based on the analysis and review of the relevant literature. Three types of analyses are found out in the literature: research topics and themes (Avison, Dwivedi, Fitzgerald, \& Powell, 2008; Claver, González, \& Llopis, 2000; D'Aubeterre, Palvia, \& Steevens, 2005; Dwivedi \& Kuljis, 2008; Ji, Min, \& Han, 2004; Palvia \& Kakhki, 2016; Palvia, Kakhki, Ghoshal, Uppala, \& Wang, 2015; Palvia et al., 2004; Palvia, Pinjani, \& Sibley, 2007; Palvia et al., 2017; Sinclaire, Simon, \& Wilkes, 2004), methodologies and research paradigms (Avison et al., 2008; Chen \& Hirschheim, 2004; Claver et al., 2000; Dwivedi \& Kuljis, 2008; Ji et al., 2004; Liu \& Myers, 2011; Myers \& Liu, 2009; Palvia \& Kakhki, 2016; Palvia et al., 2015; Palvia et al., 2004; Palvia, Mao, Salam, \& Soliman, 2003; Palvia et al., 2007; Palvia et al., 2017), and authors and universities (Avison et al., 2008; Claver et al., 2000; Dwivedi \& Kuljis, 2008; Palvia et al., 2007; Sinclaire et al., 2004). Some studies have also adopted a combination of two or three approaches. In addition, some other studies have also examined research models and paradigmatic approaches. Table 1 presents the main research studies carried out on topics and methodologies.

As shown in Table 1, with the exception of a study by Palvia et al. (Palvia et al., 2015), which covered the period ranging from 2004 to 2013, no comprehensive and recent study has been published in the top journals in the concerned field. Two other recent studies in 2016 and 2017 have reviewed specific journals (namely Information \& Management and Global Information Technology Management). Given the significance of this issue, the current study addressed this research gap as such this study analysed the topics and methodologies used in the top eight journals of information system and their trends over a 12-year period (2007-2018).

\section{Research Methodology}

Cumbie, Jourdan, Peachey, Dugo, and Craighead (2005) propose a three-stage process for literature analysis projects. In the first stage, the researcher collects a series of relevant articles. In the second stage, the researcher classified the articles into an appropriate framework. In the third stage, the researcher evaluates and combines the collected data. Accordingly, all the articles published in the top eight journals during 2007 to 2018 were first reviewed and coded. In the second stage, a two-dimensional framework encompassing topics and methodologies was created in order to classify the research papers, and each paper was then categorized with regard to the thematic and methodological dimensions. Finally, the analysis addressed practices such as comparing, connecting, and explaining the trends and results (Levy \& Ellis, 2006). The last step was to identify the gaps in research literature and predict future trends (Webster \& Watson, 2002). According to these three stages, the methodology framework of the present research is presented in Figure1. 
Mazaheri, Lagzian \& Hemmat

\begin{tabular}{|c|c|c|c|c|c|c|}
\hline Scholar & $\begin{array}{c}\text { Period } \\
\text { surveyed }\end{array}$ & Reviewed journals & First topic & Second topic & First methodology & $\begin{array}{c}\text { Second } \\
\text { methodology }\end{array}$ \\
\hline $\begin{array}{l}\text { Claver et al. } \\
2000\end{array}$ & 1997-1981 & $\begin{array}{l}\text { Information \& Management } \\
\text { MIS Quarterly }\end{array}$ & IS development & DSS & Empirical studies & Field study \\
\hline $\begin{array}{l}\text { Palvia et al. } \\
2003\end{array}$ & 1993-1997 & $\begin{array}{l}\text { Top Five Journals of } \\
\text { Information Systems }\end{array}$ & - & - & survey & $\begin{array}{l}\text { Frameworks and } \\
\text { conceptual model }\end{array}$ \\
\hline $\begin{array}{l}\text { Palvia et al. } \\
2004\end{array}$ & 1993-2003 & $\begin{array}{l}\text { Top Seven Journals of } \\
\text { Information Systems }\end{array}$ & $\begin{array}{l}\text { information systems } \\
\text { resource management }\end{array}$ & IS development & survey & $\begin{array}{l}\text { Mathematical } \\
\text { modeling }\end{array}$ \\
\hline $\begin{array}{l}\text { Chen and Hirschheim } \\
2004\end{array}$ & 1991-2001 & $\begin{array}{l}\text { Top Eight Journals of } \\
\text { Information Systems }\end{array}$ & - & - & survey & Case Study \\
\hline $\begin{array}{l}\text { D'Aubeterre et al. } \\
2005\end{array}$ & $1998-2003$ & $\begin{array}{l}\text { Top Six Journals of } \\
\text { Information Systems }\end{array}$ & $\begin{array}{l}\text { Resource } \\
\text { Management/IS } \\
\text { Management Issues }\end{array}$ & Internet & - & - \\
\hline $\begin{array}{l}\text { Palvia et al. } \\
2007\end{array}$ & 1998-2005 & Information \& Management & IS usage & $\begin{array}{l}\text { Resource Management/IS } \\
\text { Management Issues }\end{array}$ & survey & Case Study \\
\hline $\begin{array}{l}\text { Avison et al. } \\
2008\end{array}$ & 1991-2007 & Information Systems Journal & IS development & IS management & $\begin{array}{l}\text { Library research } \\
\text { literature Analysis } \\
\text { frameworks } \\
\text { conceptual modeling }\end{array}$ & Case Study \\
\hline $\begin{array}{l}\text { Dwivedi and Kuljis } \\
2008\end{array}$ & 1997-2007 & $\begin{array}{l}\text { European Journal of } \\
\text { Information Systems }\end{array}$ & IS management & IS development & Case Study & $\begin{array}{l}\text { surveys and library } \\
\text { research }\end{array}$ \\
\hline $\begin{array}{l}\text { Myers and Liu } \\
2009\end{array}$ & $1998-2007$ & $\begin{array}{l}\text { The Basket of Top Journals } \\
\text { AIS (Six Journals) }\end{array}$ & - & - & survey & Case Study \\
\hline $\begin{array}{l}\text { Palvia et al. } \\
2015\end{array}$ & 2004-2013 & $\begin{array}{l}\text { Top Seven Journals of } \\
\text { Information Systems }\end{array}$ & Electronic Commerce & IS usage /adoption & survey & $\begin{array}{l}\text { Laboratory } \\
\text { experiment }\end{array}$ \\
\hline $\begin{array}{l}\text { Palvia et al. } \\
2016\end{array}$ & 2006-2015 & $\begin{array}{l}\text { Global Information Technology } \\
\text { Management }\end{array}$ & IS usage /adoption & $\begin{array}{l}\text { Electronic commerce } \\
\text { /business- IT and culture }\end{array}$ & survey & Case Study \\
\hline $\begin{array}{l}\text { Palvia et al. } \\
2017\end{array}$ & 2004-2014 & Information \& Management & $\begin{array}{l}\text { Electronic } \\
\text { commerce/business }\end{array}$ & IS usage /adoption & survey & Field study \\
\hline
\end{tabular}

Table 1. Summary of previous studies based on the topics and methodologies used and their application priorities 


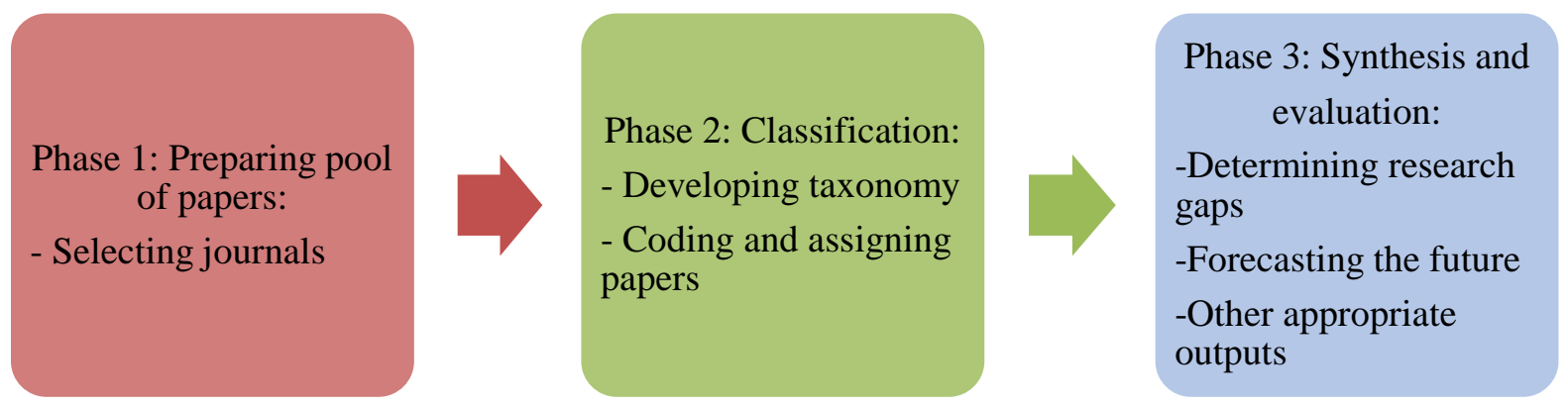

Figure 1. Research Methodology (adopted from [7] and [13])

\subsection{Journal Selection}

To create a pool of papers, the top and valid journals in the field of information systems were primarily selected; hence, the selected journals were a basket of top journals nominated introduced by the College of Senior Scholars. The College of Senior Scholars encourages colleagues, deans, and department chairs to consider a "basket" of top eight journals in the field of information system research. The College of Senior Scholars consists of professionals in the field of information systems, who have served as editors-in-chief of the concerned journals, current and former ICIS ${ }^{1}$ chairs, program chairs, and current and former heads of AIS2. This list covers the subject diversity as it contains a variety of methods and geographical information. In addition, the review processes of the concerned journals are accurate, their editorial staff are well-known and well-appreciated, and the journals have international audiences and contributors. In addition, the SJR index ("Scimago Journal \& Country Rank"), reflecting the scientific quality of a journal, were also extracted, and all the selected journals had high SJR index. Therefore, the papers from these eight journals had been collected from 2007 to 2018. A total of 3252 articles were reviewed, as listed in Table 2 by journal.

\subsection{Classification}

The researchers developed a classification framework of information system research based on several criteria.

\begin{tabular}{|l|c|c|c|}
\hline \multicolumn{1}{|c|}{ Journal } & $\begin{array}{c}\text { Number of } \\
\text { issues }\end{array}$ & $\begin{array}{c}\text { Number of } \\
\text { papers }\end{array}$ & $\begin{array}{c}\text { SJR } \\
\text { Index }\end{array}$ \\
\hline European Journal of Information Systems & 66 & 438 & 2.04 \\
\hline Information Systems Journal & 70 & 288 & 2.32 \\
\hline Information Systems Research & 48 & 542 & 3.48 \\
\hline Journal of AIS & 143 & 385 & 1.82 \\
\hline Journal of Information Technology & 48 & 335 & 2.12 \\
\hline Journal of MIS & 48 & 471 & 2.39 \\
\hline Journal of Strategic Information Systems & 48 & 227 & 1.43 \\
\hline MIS Quarterly & 48 & 566 & 4.21 \\
\hline Total & 519 & 3252 & \\
\hline
\end{tabular}

Table 2. List of Selected Journals, SJR index and Number of Papers (2007-2018)

\footnotetext{
1 The International Conference on Information Systems

${ }^{2}$ Association for Information Systems
} 
A majority of the studies using the literature analysis have focused on a combination of factors such as research topic, research model, research methodology, paradigmatic research approach, authors, and universities. In the previous section, some of the most important studies which have addressed these dimensions were mentioned. The present study focused on research topic and methodology, which are explained in the following sections.

\subsubsection{Research Methodologies}

Table 3 presents the research methodologies concerned to categorize the selected articles. The methodologies were adopted from Palvia et al. (Palvia et al., 2015). During the coding process, two titles "Social network analysis" and "Machine learning, Data mining, Text mining, and Web mining" were added. According to the previous researchers, these two methods have not fit in the previous categories and need to be considered as new methodologies. Further, it is necessary to provide a more detailed explanation about some of the concerned methodologies. First, it should be noted that the case study methodology is typically qualitative in nature; however, it can incorporate quantitative data as a part of the mixed-methods design. Accordingly, the case studies may involve both qualitative and quantitative research methods as such we distinguished it from the qualitative method.

Regarding the difference between content analysis and text mining, it can be mentioned that content analysis is "a technique for gathering and analysing the content of a text. The content refers to words, meanings, pictures, symbols, ideas, themes or any message that can be communicated" (Neuman, 2003). Content is coded into various categories or concepts depending on selected criteria (Weber, 1988), and coding can be manual or computer aided. Text mining is a computer-assisted technique to extract information and trends from large amounts of textual data (Feldman \& Sanger, 2007; Fuller, Biros, \& Delen, 2011; Tan, 1999). It is based on data mining, machine learning, and natural language processing techniques used for the texts under study. It mainly relies on computer programs and algorithms; thus, it is supposed to resolve the problems associated with the reliability of content analysis (Milne \& Adler, 1999). Text mining is thus to analyse large amounts of texts using algorithms and computer programs. In contrast, content analysis is mostly done with or without computer software to examine the underlying meaning and constructs existing in the text being analysed. Text mining is a quantitative approach, while content analysis is a qualitative one.

In survey and mathematical modelling methods, survey data can be used for regression analysis and/or hierarchical linear modelling; however, in the present study, only articles that use structured questionnaires are included in this category, and the other papers adopting analytical (e.g., formulaic, econometric, or optimization model) or descriptive (e.g., simulation) models fall into the mathematical modelling category. Table 3 shows the final classification of the methodologies. 


\begin{tabular}{|c|c|c|}
\hline & Methodology & Definition \\
\hline 1 & $\begin{array}{l}\text { Speculation / } \\
\text { commentary }\end{array}$ & $\begin{array}{l}\text { Research that derives from thinly supported arguments or opinions with } \\
\text { little or no empirical evidence }\end{array}$ \\
\hline 2 & $\begin{array}{l}\text { Frameworks and } \\
\text { conceptual model }\end{array}$ & $\begin{array}{l}\text { Research that intends to develop a framework or a conceptual } \\
\text { model. }\end{array}$ \\
\hline 3 & Literature review & Research that is based mainly on the review of existing literature. \\
\hline 4 & Literature analysis & $\begin{array}{l}\text { Research that critiques, analyzes, and extends existing literature and } \\
\text { attempts to build new groundwork, e.g., it includes a meta-analysis. }\end{array}$ \\
\hline 5 & Case study & $\begin{array}{l}\text { Study of a single phenomenon (e.g., an application, a technology, a } \\
\text { decision) in an organization over a logical time frame. }\end{array}$ \\
\hline 6 & Survey & $\begin{array}{l}\text { Research that uses predefined and structured questionnaires to capture } \\
\text { data from individuals. Normally, the questionnaires are mailed (now, fax } \\
\text { and electronic means are also used). }\end{array}$ \\
\hline 7 & Field research & $\begin{array}{l}\text { Study of single or multiple and related processes / phenomena in } \\
\text { single or multiple organizations. }\end{array}$ \\
\hline 8 & Field experiment & $\begin{array}{l}\text { Research in organizational setting that manipulates and controls the } \\
\text { various experimental variables and subjects. }\end{array}$ \\
\hline 9 & $\begin{array}{l}\text { Laboratory } \\
\text { experiment }\end{array}$ & $\begin{array}{l}\text { Research in a simulated laboratory environment that manipulates and } \\
\text { controls the various experimental variables } \\
\text { and subjects }\end{array}$ \\
\hline 10 & $\begin{array}{l}\text { Mathematical } \\
\text { modeling }\end{array}$ & $\begin{array}{l}\text { An analytical (e.g., formulaic, econometric or optimization model) or a } \\
\text { descriptive (e.g., simulation) model is developed for the phenomenon } \\
\text { under study. }\end{array}$ \\
\hline 11 & Qualitative research & $\begin{array}{l}\text { Qualitative research methods are designed to help understand } \\
\text { people and the social and cultural contexts within which they live. } \\
\text { These methods include ethnography, action research, interpretive } \\
\text { studies, and examination of documents and texts. }\end{array}$ \\
\hline 12 & Design science & $\begin{array}{l}\text { "Design science creates and evaluates IT artifacts intended to solve } \\
\text { identified organizational problems". It involves a rigorous process to } \\
\text { design artifacts to solve observed problems, to make research } \\
\text { contributions, to evaluate the designs, and to communicate the results } \\
\text { to appropriate audiences. Such artifacts may include constructs, } \\
\text { models, methods, and instantiations. }\end{array}$ \\
\hline 13 & Secondary data & $\begin{array}{l}\text { A study that utilizes existing organizational and business data, e.g., } \\
\text { financial and accounting reports, archival data, published statistics, } \\
\text { etc. }\end{array}$ \\
\hline 14 & Content analysis & $\begin{array}{l}\text { A method of analysis in which text (notes) are systematically examined } \\
\text { by identifying and grouping themes and coding, classifying and } \\
\text { developing categories. }\end{array}$ \\
\hline 15 & $\begin{array}{l}\text { Social Network } \\
\text { Analysis }\end{array}$ & $\begin{array}{l}\text { Study of the relationships of humans, organizations, groups, or any } \\
\text { other set of related entities based on graph theory. }\end{array}$ \\
\hline 16 & $\begin{array}{l}\text { Machine learning, } \\
\text { Data mining, Text } \\
\text { mining and Web } \\
\text { mining }\end{array}$ & $\begin{array}{l}\text { Machine learning (ML) is the scientific study of algorithms and } \\
\text { statistical models that computer systems use to perform a specific task } \\
\text { without using explicit instructions, relying on patterns and inference } \\
\text { instead. It is seen as a subset of artificial intelligence. } \\
\text { Data mining is the process of discovery of unknown relationships and } \\
\text { patterns within the data. } \\
\text { Text mining (text analysis) is the process of extracting high-quality } \\
\text { information from the text. } \\
\text { Web mining is a process of discovery of unknown and useful } \\
\text { information from web data. }\end{array}$ \\
\hline
\end{tabular}

Table 3. Methodologies in the Information System Research (adopted from (Palvia et al., 2015))

\subsubsection{Topics}

Alavi and Carlson (1992) first detected the most frequent research topics in the literature on information systems, and Barki et al. (Barki, Rivard, \& Talbot, 1993) developed a keyword classification scheme, which can be used as a basis for investigation IS research topics. Following the publication of these papers, the other researchers improved this topic-based classification. Some authors have adopted the construct classification proposed by AIS for 
topic analysis (Levy \& Ellis, 2006). In their paper, Palvia et al. (2004) used the top three-levels introduced by Barki et al. (Barki, Rivard, \& Talbot, 1988) to develop their topics, and later in 2015, they added some topics to the list with regard to the research discussions and topics and new trends. The same category was used in the present study, and some changes were made during the coding process and some topics were added. For example, we added topics such as 'IoT', 'Bitcoin, Block chain, Fintech', 'Digital transformation' and 'Sharing economy, Digital platform' as new topics, and IT services/Digital Services as a topic not mentioned in the previous classification. Some changes were made in the title of the categories (e.g., crowdsourcing and outsourcing categories were merged), and one of the titles was also removed from the list. Table 4 shows the final classification of the most common research topics.

\begin{tabular}{|c|c|}
\hline 1 & Big data \\
\hline 2 & Artificial intelligence/Business intelligence/data analytics/expert system \\
\hline 3 & Business process \\
\hline 4 & Cloud computing \\
\hline 5 & Customer relationship management (CRM) \\
\hline 6 & Databases \\
\hline 7 & Decision support system \& executive IS \\
\hline 8 & E-government \\
\hline 9 & Electronic commerce/business \\
\hline 10 & End user computing \\
\hline 11 & Enterprise resource planning (ERP) \\
\hline 12 & Environment of IT: internal or external \\
\hline 13 & Global information technology (GIT) \\
\hline 14 & Group support systems \\
\hline 15 & Health information technology \\
\hline 16 & Innovation/ Digital Innovation/ Digital Entrepreneurship \\
\hline 17 & Internet of things \\
\hline 18 & Internet/web \\
\hline 19 & Inter-organizational systems \\
\hline 20 & IS design and development \\
\hline 21 & IS education \\
\hline 22 & IS evaluation \\
\hline 23 & IS functional applications \\
\hline 24 & IS implementation \\
\hline 25 & IS management and planning \\
\hline 26 & IS research \\
\hline 27 & IS staffing \\
\hline 28 & IS usage/adoption \\
\hline 29 & IT and culture/ethic \\
\hline 30 & IT services/digital services \\
\hline 31 & IT value/ Business Value of IT \\
\hline 32 & Knowledge management \\
\hline 33 & Media and communications \\
\hline 34 & Mobile computing \\
\hline 35 & Organizational design \\
\hline 36 & Outsourcing and offshoring/ Crowdsourcing/ Crowd funding \\
\hline 37 & Project management \\
\hline 38 & Security and privacy \\
\hline 39 & Social media and social computing \\
\hline 40 & Social networks \\
\hline
\end{tabular}




\begin{tabular}{|l|l|}
\hline 41 & Societal issues \\
\hline 42 & Software and programming languages \\
\hline 43 & Supply chain management \\
\hline 44 & Sustainability \\
\hline 45 & Team/Virtual teams/Collaboration \\
\hline 46 & Telecommunications and networking \\
\hline 47 & Bitcoin / Block chain / Fintech \\
\hline 48 & Sharing economy/Digital platform \\
\hline 49 & Digital transformation \\
\hline
\end{tabular}

Table 4. List of Topic Categories

\subsection{Coding}

While each article normally has a main topic and a dominant methodology, some papers deal with multiple topics and may use several methodologies. As a result, to include to such papers in the present study, in the coding file for each paper, three columns were designed for the topic(s) and two columns for methodology.

Accordingly, a total of 3252 papers published from 2007 to 2018, belonging to a basket of the top eight IS journals, were reviewed and codified using the proposed framework. To determine the research topics, each paper was analysed by title, keywords, and abstract. This approach has been adopted by several authors (Avison et al., 2008; Farhoomand \& Drury, 1999; Palvia et al., 2015). To determine the research methodologies, the abstract and content of the papers were reviewed.

Three experts (including the researcher and two assistants) coded the articles individually. To achieve reliable results and increase reliability of this process, the following points were considered by the coders:

- In order to increase the coding uniformity and reduce the ambiguity, the coders had several meetings before coding and exchanged the necessary information. Finally, they, to some extent, came to an agreement on the encoding process.

- In the methodology section, standard definitions of the methodologies were provided for the coders to avoid coding mistakes.

- To remove the effect of the chance from the calculations, the inter-coder reliability was estimated.

Inter-coder reliability was calculated in a two-phase process. In the first phase, the coders encoded 50 papers independently and then compared their results. Table 5 shows the results of the first phase.

\begin{tabular}{|c|l|l|l|}
\hline Coder & \multicolumn{1}{|c|}{$\mathbf{1}$} & \multicolumn{1}{|c|}{$\mathbf{2}$} & $\mathbf{3}$ \\
\hline $\mathbf{1}$ & & & \\
\hline 2 & $75 \%$ (Topic) & & \\
\hline 3 & $63 \%$ (Methodology) & & \\
\hline
\end{tabular}

Table 5. Phase One of Inter-Coder Reliability (By topic and methodology) 
As shown in Table 5, inter-coder reliability is not at 90\%, a level of significance recommended in the relevant literature (Palvia et al., 2004); therefore, the authors discussed their findings in several sessions in the cases of inconsistency in order to reach a common understanding. In the second phase of the coding process, the coders coded 25 papers, and the results of intercoder reliability are presented in Table 6 .

\begin{tabular}{|c|l|l|l|}
\hline Coder & \multicolumn{1}{|c|}{$\mathbf{1}$} & \multicolumn{1}{|c|}{$\mathbf{2}$} & \multicolumn{1}{|c|}{$\mathbf{3}$} \\
\hline $\mathbf{1}$ & & & \\
\hline $\mathbf{2}$ & $\begin{array}{l}93 \% \text { (Topic) } \\
89 \% \text { (Methodology) }\end{array}$ & & \\
\hline $\mathbf{3}$ & $\begin{array}{l}94 \% \text { (Topic) } \\
91 \% \text { (Methodology) }\end{array}$ & $\begin{array}{l}98 \% \text { (Topic) } \\
93 \% \text { (Methodology) }\end{array}$ & \\
\hline
\end{tabular}

Table 6. Phase Two Inter-Coder Reliability (By topic and methodology)

As it can be noticed, all coders achieved reliability at an acceptable level in this phase.

\section{Results}

In this section, the results are presented based on the topic and methodology of the concerned articles, for which the main thematic points and methodology as well as the major trends are discussed separately.

\subsection{The process of using information systems methodologies}

Table 7 lists the most frequently used research methodologies in the top eight journals during a twelve-year period. Since two methodologies were considered in coding for each paper (since a paper may use a combination of two methodologies, for example, survey and qualitative methods), two columns (namely primary and secondary methodologies) are devoted to methodology in the Table. For each methodology in Table 7, four values are presented: Number of times a methodology was used as the primary methodology, number of times a methodology was used as a secondary methodology, total number of times a methodology was used, and the percentage of using a methodology.

As it can be seen in Table 7, in the journals studied during a twelve-year period (2007-2018), the survey method was the most common methodology (19.3\%). The other frequently used methodologies were mathematical modelling $(17 \%)$, case study $(13.8 \%)$, qualitative research (11\%) and literature review (7\%), respectively.

Table 8 shows the significant trends by year and the priority of methodologies per year during a 12-year period. Figure 2 also graphically illustrates the methodologies used during 2007 to 2018. 


\begin{tabular}{|c|c|c|c|c|c|}
\hline Methodology & $\begin{array}{c}\text { Primary } \\
\text { methodolo } \\
\text { gy } \\
\text { count } \\
\end{array}$ & $\begin{array}{c}\text { Secondary } \\
\text { methodolo } \\
\text { gy } \\
\text { count }\end{array}$ & $\begin{array}{c}\text { Total } \\
\text { Papers }\end{array}$ & Total $(\%)$ & $\begin{array}{l}\text { Rank by } \\
\text { total }\end{array}$ \\
\hline Survey & 609 & 62 & 671 & $19.3 \%$ & 1 \\
\hline Mathematical modeling & 560 & 30 & 590 & $17 \%$ & 2 \\
\hline Case study & 464 & 14 & 478 & $13.8 \%$ & 3 \\
\hline Qualitative research & 354 & 29 & 383 & $11 \%$ & 4 \\
\hline Literature review & 243 & 0 & 243 & $7 \%$ & 5 \\
\hline Laboratory experiment & 197 & 15 & 212 & $6.1 \%$ & 6 \\
\hline Speculation/commentary & 194 & 1 & 195 & $5.6 \%$ & 7 \\
\hline Frameworks and conceptual model & 133 & 5 & 138 & $4 \%$ & 8 \\
\hline Secondary data & 104 & 26 & 130 & $3.7 \%$ & 9 \\
\hline Field research & 101 & 9 & 110 & $3.2 \%$ & 10 \\
\hline Field experiment & 99 & 4 & 103 & $3 \%$ & 11 \\
\hline Design science & 59 & 1 & 60 & $1 / 7 \%$ & 12 \\
\hline Literature analysis & 55 & 0 & 55 & $1 / 6 \%$ & 13 \\
\hline $\begin{array}{l}\text { Machine learning, Data mining, Text } \\
\text { mining and Web mining }\end{array}$ & 44 & 2 & 46 & $1 / 3 \%$ & 14 \\
\hline Content analysis & 21 & 14 & 35 & $1 \%$ & 15 \\
\hline Social Network Analysis & 15 & 6 & 21 & $0 / 6 \%$ & 16 \\
\hline Total & 3252 & 218 & 3470 & $100 \%$ & \\
\hline
\end{tabular}

Table 7. Rank of Research Methodology Based on Count and Percentage of Papers Using a particular methodology 


\begin{tabular}{|c|c|c|c|c|c|c|c|c|c|c|c|c|c|c|}
\hline Æֶ̆ & Methodology & 옹 & 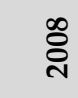 & 옹 & 옹 & 쿵 & ำรำ & $\stackrel{m}{\stackrel{2}{*}}$ & 芦 & 롱 & 룰 & 룽 & $\stackrel{\infty}{\stackrel{\infty}{*}}$ & 胥 \\
\hline 1 & Survey & 61 & 46 & 51 & 61 & 74 & 59 & 49 & 53 & 69 & 45 & 56 & 47 & 671 \\
\hline 2 & $\begin{array}{l}\text { Mathematical } \\
\text { modeling }\end{array}$ & 31 & 26 & 30 & 44 & 42 & 77 & 55 & 55 & 47 & 50 & 61 & 72 & 590 \\
\hline 3 & Case study & 54 & 50 & 42 & 33 & 45 & 40 & 46 & 47 & 31 & 33 & 25 & 32 & 478 \\
\hline 4 & $\begin{array}{l}\text { Qualitative } \\
\text { research }\end{array}$ & 21 & 31 & 34 & 39 & 27 & 18 & 36 & 35 & 21 & 31 & 50 & 40 & 383 \\
\hline 5 & Literature review & 33 & 22 & 22 & 19 & 27 & 30 & 21 & 12 & 19 & 16 & 13 & 9 & 243 \\
\hline 6 & $\begin{array}{l}\text { Laboratory } \\
\text { experiment }\end{array}$ & 9 & 20 & 17 & 13 & 24 & 10 & 23 & 20 & 15 & 21 & 19 & 21 & 212 \\
\hline 7 & $\begin{array}{l}\text { Speculation / } \\
\text { commentary }\end{array}$ & 12 & 17 & 6 & 36 & 25 & 31 & 8 & 18 & 17 & 17 & 4 & 4 & 195 \\
\hline 8 & $\begin{array}{l}\text { Frameworks and } \\
\text { conceptual model }\end{array}$ & 15 & 11 & 15 & 10 & 10 & 17 & 13 & 9 & 7 & 8 & 8 & 15 & 138 \\
\hline 9 & Secondary data & 4 & 9 & 10 & 17 & 10 & 17 & 12 & 7 & 20 & 13 & 6 & 5 & 130 \\
\hline 10 & Field research & 7 & 6 & 5 & 12 & 9 & 18 & 10 & 13 & 5 & 5 & 12 & 8 & 110 \\
\hline 11 & Field experiment & 3 & 5 & 10 & 8 & 6 & 6 & 12 & 8 & 12 & 15 & 13 & 5 & 103 \\
\hline 12 & Design science & 1 & 9 & 3 & 2 & 1 & 7 & 4 & 6 & 8 & 8 & 9 & 2 & 60 \\
\hline 13 & $\begin{array}{l}\text { Literature } \\
\text { analysis }\end{array}$ & 5 & 5 & 5 & 4 & 4 & 6 & 6 & 4 & 5 & 5 & 2 & 4 & 55 \\
\hline 14 & $\begin{array}{l}\text { Machine } \\
\text { learning, Data } \\
\text { mining, Text } \\
\text { mining and Web } \\
\text { mining }\end{array}$ & 1 & 1 & 0 & 2 & 0 & 1 & 2 & 3 & 0 & 5 & 10 & 21 & 46 \\
\hline 15 & Content analysis & 4 & 1 & 4 & 4 & 0 & 3 & 2 & 3 & 5 & 5 & 2 & 2 & 35 \\
\hline 16 & $\begin{array}{l}\text { Social Network } \\
\text { Analysis }\end{array}$ & 2 & 1 & 2 & 2 & 2 & 1 & 1 & 2 & 0 & 4 & 1 & 3 & 21 \\
\hline \multicolumn{2}{|l|}{ Total } & 263 & 260 & 256 & 306 & 306 & 341 & 300 & 295 & 281 & 281 & 291 & 290 & 3470 \\
\hline
\end{tabular}

Table 8 - Methodology trends over the years 2007-2018

Survey method was the most-oft used research method in almost each year. The mathematical model also experienced a rising trend during this period and reached its peak in 2012. The other significant trend was a decline in the use of conceptual modelling and framework 
methodology. Although the use of this methodology reached its peak in 2012, it was least used in 2015, 2016, and 2017. The use of this methodology, however, increased in 2018 once more.

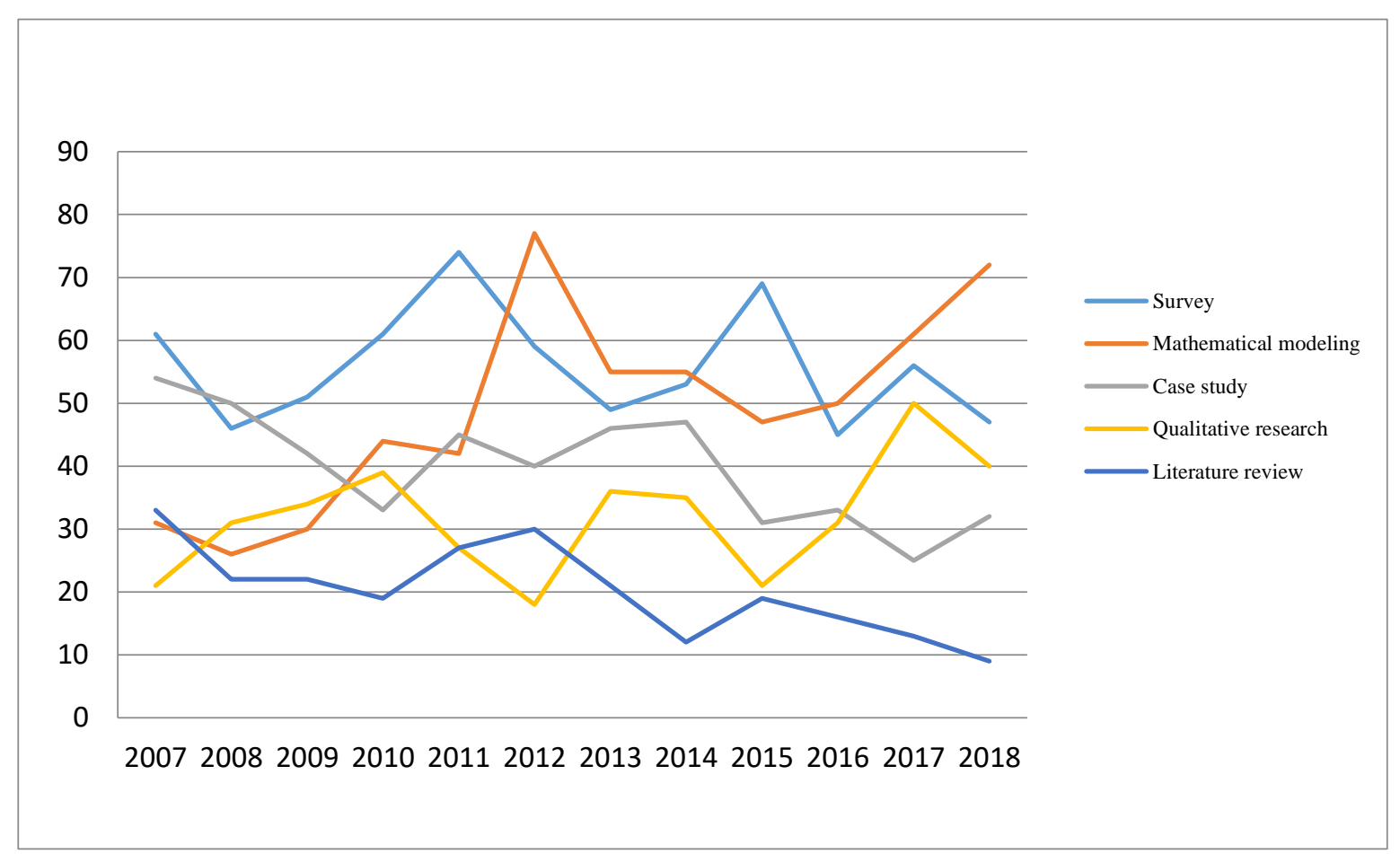

Figure 2 - The top 5 Methodologies in the Period (2007-2018)

\subsection{Topic trends of information systems}

Table 9 shows the frequency and percentage of the topics covered in all papers published from 2007 to 2018 in the top eight journals by year. Electronic commerce/business, information system research, and information system usage/adoption are the most frequently studied topics, with the "electronic commerce/business" being at the top of the list, having an $8.95 \%$ frequency. Information system research and information system usage/adoption are ranked next with the frequencies of 7.82 and 7.36 percent, respectively. In addition to these three topics, seven other common topics are information system management and planning $(6.89 \%)$, security and privacy $(6.31 \%)$, software and programming language $(4.72 \%)$, outsourcing and offshoring/crowdsourcing (4.54\%), social media and social computing (4.41\%), knowledge management (3.81\%), and IT value/ Business Value of IT (3.31\%).

Regarding the topic trends, there is an increasing attention to social media, social network, and big data. Moreover, IoT was also discussed for the first time in 2016. Bitcoin / block chain / Fintech, sharing economy/digital platform and digital transformation were also first presented as research topics in 2017 and 2018. Figure 3 illustrates an analysis of these ten frequent topics. 


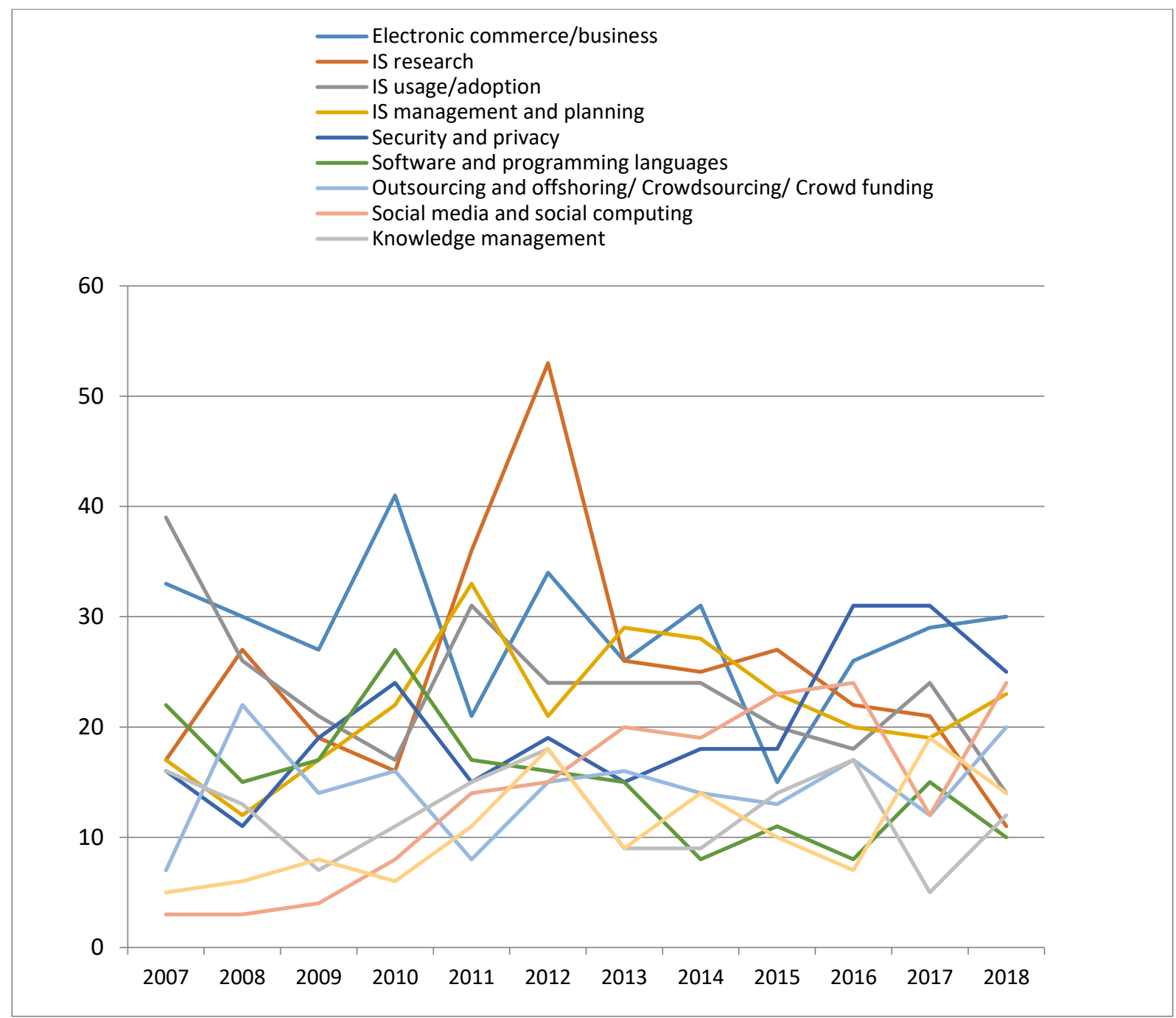

Figure 3. The top ten topics in the period (2007-2018) 


\begin{tabular}{|c|c|c|c|c|c|c|c|c|c|c|c|c|c|c|c|}
\hline$\underset{\widetilde{\Xi}}{\tilde{\Xi}}$ & Topic & હે & ڤ్రి & ஓ्रे & 율 & 궁 & 곡 & $\stackrel{m}{\stackrel{\rho}{\nu}}$ & ఫ্ণ & 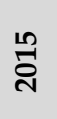 & 穴 & 동 & $\stackrel{\infty}{\stackrel{2}{*}}$ & $\underset{0}{0}$ & 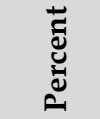 \\
\hline 1 & $\begin{array}{l}\text { Electronic commerce / } \\
\text { business }\end{array}$ & 33 & 30 & 27 & 41 & 21 & 34 & 26 & 31 & 15 & 26 & 29 & 30 & 343 & $8.95 \%$ \\
\hline 2 & IS research & 17 & 27 & 19 & 16 & 36 & 53 & 26 & 25 & 27 & 22 & 21 & 11 & 300 & $7.82 \%$ \\
\hline 3 & IS usage/adoption & 39 & 26 & 21 & 17 & 31 & 24 & 24 & 24 & 20 & 18 & 24 & 14 & 282 & $7.36 \%$ \\
\hline 4 & $\begin{array}{l}\text { IS management and } \\
\text { planning }\end{array}$ & 17 & 12 & 17 & 22 & 33 & 21 & 29 & 28 & 23 & 20 & 19 & 23 & 264 & $6.89 \%$ \\
\hline 5 & Security and privacy & 16 & 11 & 19 & 24 & 15 & 19 & 15 & 18 & 18 & 31 & 31 & 25 & 242 & $6.31 \%$ \\
\hline 6 & $\begin{array}{l}\text { Software and programming } \\
\text { languages }\end{array}$ & 22 & 15 & 17 & 27 & 17 & 16 & 15 & 8 & 11 & 8 & 15 & 10 & 181 & $4.72 \%$ \\
\hline 7 & $\begin{array}{l}\text { Outsourcing and offshoring } \\
\text { / Crowdsourcing / Crowd } \\
\text { funding }\end{array}$ & 7 & 22 & 14 & 16 & 8 & 15 & 16 & 14 & 13 & 17 & 12 & 20 & 174 & $4.54 \%$ \\
\hline 8 & $\begin{array}{l}\text { Social media and social } \\
\text { computing }\end{array}$ & 3 & 3 & 4 & 8 & 14 & 15 & 20 & 19 & 23 & 24 & 12 & 24 & 169 & $4.41 \%$ \\
\hline 9 & Knowledge management & 16 & 13 & 7 & 11 & 15 & 18 & 9 & 9 & 14 & 17 & 5 & 12 & 146 & $3.81 \%$ \\
\hline 10 & $\begin{array}{l}\text { IT value / Business Value of } \\
\text { IT }\end{array}$ & 5 & 6 & 8 & 6 & 11 & 18 & 9 & 14 & 10 & 7 & 19 & 14 & 127 & $3.31 \%$ \\
\hline 11 & Social networks & 2 & 6 & 0 & 14 & 5 & 6 & 10 & 10 & 17 & 12 & 19 & 13 & 114 & $2.97 \%$ \\
\hline 12 & IS design and development & 13 & 8 & 11 & 16 & 9 & 13 & 13 & 5 & 2 & 7 & 10 & 6 & 113 & $2.95 \%$ \\
\hline 13 & $\begin{array}{l}\text { Health information } \\
\text { technology }\end{array}$ & 20 & 3 & 5 & 3 & 17 & 5 & 5 & 8 & 9 & 11 & 18 & 9 & 113 & $2.95 \%$ \\
\hline 14 & $\begin{array}{l}\text { Innovation / } \\
\text { Digital Innovation / } \\
\text { Digital Entrepreneurship }\end{array}$ & 8 & 7 & 5 & 9 & 5 & 7 & 8 & 7 & 9 & 7 & 16 & 9 & 97 & $2.53 \%$ \\
\hline 15 & Internet / web & 3 & 2 & 7 & 8 & 8 & 13 & 7 & 9 & 8 & 5 & 6 & 6 & 82 & $2.14 \%$ \\
\hline
\end{tabular}




\begin{tabular}{|c|c|c|c|c|c|c|c|c|c|c|c|c|c|c|c|}
\hline 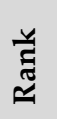 & Topic & હે & ஓ̊. & ㅇํㅇ & 을 & 콩 & ్ㅗㅇ & $\stackrel{m}{\stackrel{2}{\nu}}$ & 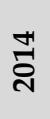 & 롱 & 穴 & จे & $\stackrel{\infty}{\stackrel{\sim}{*}}$ & $\stackrel{\text { Tే }}{0}$ & 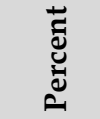 \\
\hline 16 & $\begin{array}{l}\text { Team / Virtual teams / } \\
\text { Collaboration }\end{array}$ & 5 & 6 & 12 & 8 & 4 & 11 & 2 & 3 & 6 & 2 & 4 & 12 & 75 & $1.96 \%$ \\
\hline 17 & $\begin{array}{l}\text { Business intelligence / data } \\
\text { analytics/expert system }\end{array}$ & 2 & 2 & 3 & 2 & 3 & 13 & 3 & 8 & 4 & 10 & 12 & 9 & 71 & $1.85 \%$ \\
\hline 18 & Project management & 5 & 5 & 7 & 8 & 2 & 2 & 9 & 9 & 3 & 6 & 5 & 3 & 64 & $1.67 \%$ \\
\hline 19 & Mobile computing & 3 & 3 & 9 & 3 & 1 & 2 & 6 & 9 & 12 & 5 & 3 & 5 & 61 & $1.59 \%$ \\
\hline 20 & IS implementation & 3 & 5 & 6 & 4 & 7 & 6 & 11 & 4 & 2 & 3 & 1 & 3 & 55 & $1.43 \%$ \\
\hline 21 & $\begin{array}{l}\text { Media and } \\
\text { communications }\end{array}$ & 5 & 6 & 3 & 8 & 2 & 3 & 5 & 9 & 2 & 7 & 1 & 3 & 54 & $1.41 \%$ \\
\hline 22 & $\begin{array}{l}\text { Decision support system \& } \\
\text { executive IS }\end{array}$ & 2 & 3 & 2 & 6 & 6 & 2 & 1 & 6 & 3 & 3 & 8 & 8 & 50 & $1.30 \%$ \\
\hline 23 & IS staffing & 8 & 3 & 2 & 1 & 5 & 6 & 3 & 3 & 4 & 5 & 2 & 7 & 49 & $1.28 \%$ \\
\hline 24 & $\begin{array}{l}\text { Telecommunications and } \\
\text { networking }\end{array}$ & 4 & 3 & 10 & 5 & 6 & 5 & 6 & 3 & 2 & 1 & 2 & 1 & 48 & $1.25 \%$ \\
\hline 25 & E-government & 13 & 7 & 1 & 5 & 7 & 3 & 3 & 2 & 1 & 3 & 0 & 2 & 47 & $1.23 \%$ \\
\hline 26 & IT services / digital services & 0 & 3 & 4 & 1 & 2 & 3 & 5 & 1 & 7 & 3 & 7 & 10 & 46 & $1.20 \%$ \\
\hline 27 & IT and culture / ethic & 7 & 3 & 3 & 3 & 4 & 3 & 3 & 5 & 8 & 1 & 0 & 5 & 45 & $1.17 \%$ \\
\hline 28 & $\begin{array}{l}\text { Inter-organizational } \\
\text { systems }\end{array}$ & 3 & 7 & 4 & 6 & 5 & 2 & 4 & 4 & 1 & 1 & 5 & 2 & 44 & $1.15 \%$ \\
\hline 29 & $\begin{array}{l}\text { Enterprise resource } \\
\text { planning (ERP) }\end{array}$ & 6 & 6 & 4 & 6 & 3 & 3 & 2 & 0 & 4 & 3 & 1 & 0 & 38 & $0.99 \%$ \\
\hline 30 & Business process & 4 & 5 & 2 & 6 & 2 & 4 & 2 & 3 & 4 & 3 & 2 & 0 & 37 & $0.97 \%$ \\
\hline 31 & Sustainability & 0 & 0 & 1 & 4 & 8 & 0 & 4 & 2 & 1 & 5 & 9 & 1 & 35 & $0.91 \%$ \\
\hline
\end{tabular}




\begin{tabular}{|c|c|c|c|c|c|c|c|c|c|c|c|c|c|c|c|}
\hline 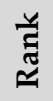 & Topic & 옹 & 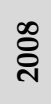 & ஓ् & 울 & 궁 & 궁 & $\stackrel{m}{\stackrel{\sim}{\sim}}$ & 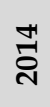 & 룽 & 울 & 공 & $\stackrel{\infty}{\stackrel{\sim}{\sim}}$ & సే & 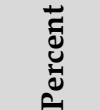 \\
\hline 32 & Societal issues & 0 & 5 & 1 & 1 & 2 & 1 & 4 & 7 & 3 & 4 & 1 & 3 & 32 & $0.83 \%$ \\
\hline 33 & Big data & 0 & 0 & 0 & 0 & 0 & 1 & 0 & 0 & 9 & 11 & 3 & 7 & 31 & $0.81 \%$ \\
\hline 34 & Cloud computing & 0 & 0 & 2 & 0 & 1 & 1 & 3 & 2 & 4 & 6 & 2 & 8 & 29 & $0.76 \%$ \\
\hline 35 & Supply chain management & 2 & 2 & 7 & 3 & 7 & 1 & 2 & 0 & 1 & 1 & 1 & 1 & 28 & $0.73 \%$ \\
\hline 36 & End user computing & 2 & 4 & 0 & 4 & 2 & 2 & 0 & 3 & 4 & 0 & 2 & 0 & 23 & $0.60 \%$ \\
\hline 37 & $\begin{array}{l}\text { Bitcoin / Block chain / } \\
\text { Fintech }\end{array}$ & 0 & 0 & 0 & 0 & 0 & 0 & 0 & 0 & 0 & 0 & 6 & 11 & 17 & $0.44 \%$ \\
\hline 38 & Databases & 2 & 1 & 1 & 3 & 2 & 3 & 1 & 1 & 0 & 1 & 0 & 1 & 16 & $0.42 \%$ \\
\hline 39 & $\begin{array}{l}\text { Sharing economy / Digital } \\
\text { Platform }\end{array}$ & 0 & 0 & 0 & 0 & 0 & 0 & 0 & 0 & 0 & 0 & 3 & 13 & 16 & $0.42 \%$ \\
\hline 40 & IS education & 2 & 1 & 2 & 6 & 0 & 0 & 1 & 1 & 0 & 0 & 0 & 1 & 14 & $0.37 \%$ \\
\hline 41 & $\begin{array}{l}\text { Environment of IT: internal } \\
\text { or external }\end{array}$ & 0 & 0 & 0 & 3 & 3 & 2 & 1 & 1 & 0 & 1 & 0 & 0 & 11 & $0.29 \%$ \\
\hline 42 & Group support systems & 0 & 3 & 3 & 1 & 1 & 2 & 0 & 0 & 0 & 0 & 0 & 0 & 10 & $0.26 \%$ \\
\hline 43 & $\begin{array}{l}\text { Customer relationship } \\
\text { management (CRM) }\end{array}$ & 1 & 0 & 0 & 1 & 3 & 3 & 0 & 0 & 0 & 0 & 1 & 1 & 10 & $0.26 \%$ \\
\hline 44 & $\begin{array}{l}\text { Global information } \\
\text { technology (GIT) }\end{array}$ & 1 & 2 & 1 & 2 & 0 & 1 & 0 & 0 & 0 & 1 & 1 & 0 & 9 & $0.23 \%$ \\
\hline 45 & IS functional applications & 2 & 1 & 0 & 1 & 0 & 1 & 1 & 0 & 0 & 0 & 0 & 0 & 6 & $0.16 \%$ \\
\hline 46 & Internet of things & 0 & 0 & 0 & 0 & 0 & 0 & 0 & 0 & 0 & 1 & 3 & 1 & 5 & $0.13 \%$ \\
\hline 47 & IS evaluation & 1 & 0 & 1 & 1 & 0 & 0 & 0 & 1 & 0 & 0 & 0 & 0 & 4 & $0.10 \%$ \\
\hline
\end{tabular}




\begin{tabular}{|c|c|c|c|c|c|c|c|c|c|c|c|c|c|c|c|}
\hline $\begin{array}{l}\text { है } \\
\text { Е }\end{array}$ & Topic & ثิે & ఫั & ઠ્ંે & ัํำ & $\overline{\text { กี }}$ & สิ๋ & ڤ్రి & تี่ & ํㅗํ & ปี & సิ & 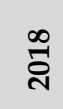 & $\begin{array}{l}\text { Jँّ } \\
0\end{array}$ & $\begin{array}{l}\overrightarrow{\vec{\Xi}} \\
\text { Uूँ }\end{array}$ \\
\hline 48 & Organizational design & 0 & 0 & 1 & 1 & 0 & 1 & 1 & 0 & 0 & 0 & 0 & 0 & 4 & $0.10 \%$ \\
\hline 49 & Digital transformation & 0 & 0 & 0 & 0 & 0 & 0 & 0 & 0 & 0 & 0 & 0 & 3 & 3 & $0.08 \%$ \\
\hline Tota & & 304 & 277 & 273 & 341 & 333 & 364 & 315 & 316 & 304 & 321 & 341 & 347 & 3834 & $100 \%$ \\
\hline
\end{tabular}

Note: The total number of topics is more than the number of papers because of possible multiple topics per paper.

Table 9. Ranking of research topics over years 2007-2018 by year 


\subsection{Publication Patterns of Journals}

Although most information system journals accept and publish articles on all aspects of the information system, the journals may have their own specific orientations based on their specific conditions, including history, editors, reviewers, and even authors. In this section, the topics and research methods of each journal are examined and compared.

Table 10 shows the publication patterns of the top ten topics in the eight journals, and Table 11 presents the research methods adopted in the studies published in the concerned journals.

\begin{tabular}{|l|c|c|c|c|c|c|c|c|}
\hline \multicolumn{1}{|c|}{ Top topics (10) } & EJIS & ISJ & ISR & JAIS & JIT & JMIS & JSIS & MISQ \\
\hline Electronic commerce / business & 26 & 14 & 106 & 20 & 16 & 78 & 17 & 66 \\
\hline IS research & 58 & 26 & 17 & 53 & 69 & 9 & 7 & 61 \\
\hline IS usage / adoption & 45 & 28 & 34 & 48 & 22 & 31 & 15 & 59 \\
\hline IS management and planning & 50 & 23 & 40 & 25 & 32 & 26 & 33 & 35 \\
\hline Security and privacy & 30 & 13 & 43 & 27 & 6 & 62 & 12 & 49 \\
\hline Software and programming languages & 28 & 17 & 40 & 18 & 9 & 34 & 13 & 22 \\
\hline $\begin{array}{l}\text { Outsourcing and offshoring / } \\
\text { Crowdsourcing / Crowd funding }\end{array}$ & 13 & 9 & 33 & 7 & 25 & 26 & 30 & 31 \\
\hline Social media and social computing & 4 & 10 & 45 & 13 & 8 & 32 & 9 & 48 \\
\hline Knowledge management & 14 & 27 & 16 & 10 & 16 & 23 & 20 & 20 \\
\hline IT value / Business Value of IT & 11 & 3 & 34 & 11 & 8 & 24 & 11 & 25 \\
\hline
\end{tabular}

Table 10. Number of papers representing the top 10 topics, by journal

As it can be seen in Table 10, some topics have been of a greater interest in some Journals. For example, the topic 'electronic commerce' is most frequently addressed in Information Systems Research Journal, and the topic 'information system research' is most frequently observed in MISQ and the Journal of Information Technology.

\begin{tabular}{|l|c|c|c|c|c|c|c|c|}
\hline \multicolumn{1}{|c|}{ Methodology } & EJIS & ISJ & ISR & JAIS & JIT & JMIS & JSIS & MISQ \\
\hline Survey & 123 & 67 & 90 & 71 & 41 & 118 & 60 & 101 \\
\hline Case study & 101 & 87 & 22 & 46 & 87 & 28 & 60 & 47 \\
\hline $\begin{array}{l}\text { Frameworks and conceptual } \\
\text { model }\end{array}$ & 21 & 13 & 6 & 38 & 14 & 7 & 10 & 29 \\
\hline Qualitative research & 78 & 75 & 26 & 44 & 40 & 31 & 36 & 53 \\
\hline Speculation/ commentary & 29 & 4 & 27 & 23 & 73 & 0 & 8 & 31 \\
\hline Literature review & 18 & 23 & 5 & 70 & 46 & 16 & 27 & 38 \\
\hline Literature analysis & 18 & 5 & 1 & 4 & 12 & 1 & 5 & 9 \\
\hline Field research & 10 & 8 & 24 & 11 & 7 & 16 & 3 & 31 \\
\hline Field experiment & 6 & 2 & 34 & 6 & 3 & 23 & 1 & 28 \\
\hline Laboratory experiment & 13 & 11 & 48 & 36 & 3 & 56 & 2 & 43 \\
\hline Mathematical modeling & 22 & 4 & 237 & 24 & 8 & 139 & 14 & 142 \\
\hline Design science & 8 & 3 & 3 & 16 & 0 & 14 & 2 & 14 \\
\hline Secondary data & 8 & 3 & 44 & 6 & 7 & 31 & 10 & 21 \\
\hline Content analysis & 9 & 5 & 4 & 6 & 2 & 5 & 0 & 4 \\
\hline Social Network Analysis & 2 & 2 & 8 & 2 & 3 & 3 & 1 & 0 \\
\hline $\begin{array}{l}\text { Machine learning, Data mining, } \\
\text { Text mining and Web mining }\end{array}$ & 3 & 0 & 8 & 1 & 3 & 19 & 0 & 12 \\
\hline
\end{tabular}

Table 11. Number of papers representing each methodology by journal 
Regarding the research methods, the European Journal of Information Systems and the Journal of MIS have published the largest number of papers with survey method; however, Information Systems Research Journal contains the largest number of papers using mathematical modelling.

\section{Discussion and Conclusion}

Information system is an emerging and unique discipline, which is constantly experiencing rapid changes as such understanding the topics and research methods used in this field and the trend of the changes in this regard can be useful for researchers in the field of information systems. Accordingly, this study detected the trends in the field of information system research over a twelve-year period (2007-2018) using a comprehensive literature analysis approach.

\subsection{Topics and their trends during 2007-2018}

The first objective of this study was to investigate the topics used by researchers and their trends during a 12-year period. To this end, 3252 articles from the top eight information system journals were reviewed and analysed by three coders. Accordingly, several findings were achieved. First, the analyses showed that electronic commerce/business received higher attention among the other topics. This field of research dramatically caught the attention of many researchers with the advent of the Internet. With revolutionary advances in Internet technology and relevant software and applications to facilitate e-commerce, the research in this area continues to grow. This finding is in line with the findings of previous studies (e.g., Palvia et al., 2015).

Information system research is another area which has been addressed frequently. In some other review studies (Avison et al., 2008; Palvia et al., 2015), this field was also ranked third. The present study refers to research papers on information system dimensions such as models, methods, paradigms and theories. Considering the emerging and interdisciplinary nature of information system and the need to address paradigms, models, new methodologies and theories in this field, this topic seems to be of interest in future studies.

The third area of research is the usage and acceptance of information systems. In a large number of previous studies, this area has been among the top three issues (Palvia et al., 2015; Palvia et al., 2004; Palvia et al., 2007; Sinclaire et al., 2004). The turning point of research on the usage and acceptance of information systems was emerged following Davis' (Davis, 1989) study on technology acceptance model. Afterwards, many researchers have increasingly addressed this issue in various Journals so that the research on this topic has remarkably grown.

\subsection{Methodologies and their trends during 2007-2018}

As the second objective of the study, the researchers were to detect the most common research methodologies and their trends. The findings showed that most of the published papers are empirical studies and have used a survey method for data collection. This finding is consistent with the findings of some other studies (Chen \& Hirschheim, 2004; Myers \& Liu, 2009; Palvia et al., 2015; Palvia et al., 2004; Palvia et al., 2003; Palvia et al., 2007). Information system researchers generally prefer to use survey method so that more than a quarter of the reviewed papers adopted this method to collect data. However, the results also revealed that that some recent researchers have also adopted qualitative and case study methods since these methods provide a deep, precise, and clear understanding of a phenomenon under study. The second 
most popular methodology was the mathematical model. In this study, a wide range of methods such as analytical models, formula-dependent models, optimization models, algorithms, multi-criteria decision-making, Bayesian Networks, hierarchical linear modelling, regression analysis, panel co-integration analysis, Multiple Indicators-Multiple Causes were also in this category. Such an increased attention indicates that the authors are seeking to increase the accuracy of the research through adopting mathematical, quantitative, and complex methods.

\subsection{Research Gaps and Future Trends}

The third objective of this paper was to identify research gaps and predict the future trends in the field of information system research. In this regard, a few points should be noted. First, the topics 'IoT', 'bitcoin / block chain / Fintech', 'sharing economy/digital platform' and digital transformation have been recently raised in the field of information systems as such they have not been included in previous classifications; hence, the future researchers are more likely to focus on these issues.

Researchers have identified these issues based on the analysis of papers published during the research period. In other words, in recent years due to rapid innovation in information technology, new subject areas and issues emerging from these resulted in publications that did not fit previously identified subject areas and issues. Researchers identified these issues by reviewing papers during the coding process. These categories were confirmed by attending conferences, typically, the first places where new research comes to light. Evidence to supporting the identification of new topics was obtained by examining conference topic lists. For example, in the International Conference on Information Systems (2020), in Track Descriptions Section, the following topics were introduced as new research topics: 'block chain, DLT, and Fintech', 'sharing economy, platforms, and crowds', 'digital innovation, entrepreneurship, and new business models', and 'IoT and the smart connected world'. In Pacific Asia Conference on Information Systems (2020), in Track Descriptions Section, the following topics were considered as new research topics: 'block chain, Fintech, and emerging technologies', 'sharing economy', 'digital transformation and social impact in the MENA Region'.

Second, the topic 'Big Data' was first posed in 2012 in the concerned journals and experienced a relatively large growth in 2015 and 2016. Today, with the advent of technologies, various devices and equipment such as mobile phones, environmental sensors, various software logos, cameras, microphones, RFID detection devices, wireless sensor networks, social networks, and data production are increasing at a dazzling speed. Accordingly, the large volume of information available to organizations, on the one hand, and the complexity of societies and organizations and the increasing need for decisive decisions based on this comprehensive information, on the other hand, require an established alignment between business needs and information system research in this field. This topic, thus, seems to be one of the would-be research areas.

The other interesting trend is social media, which has also been of great interest over the past twelve years. Given its high popularity among users and its widespread use, this topic is likely to be the focus of attention in the future.

Regarding the research methodology, a significant trend is to decrease the use of framework methods and conceptual models. Although it was greatly used in 2012, it was less addressed 
in 2015, 2016, and 2017. Once more, this topic became the hotbed of debate in 2018. These results suggest that the journals are more inclined to publish the real research more than the frameworks guiding the research studies.

The other notable trend is the increasing use of machine learning and data mining over the last two years. According to the descriptions on big data and given the enormous amount of information available, these methods are suggested for the analyses as such they would be more widely used in the future.

Finally, the present study contributes to the existing literature by providing a detailed and relatively comprehensive overview of the information system studies in authentic journals and comparing the results. Moreover, the novelty of this research lies in its being up-to-date and including a larger number of top journals.

One of the limitations of the present research was that only eight journals were investigated. Although a large number of the leading experts and authors in the field of information system have published their papers in these journals, there are some other specialized journals such as Decision Support Systems, Journal of Global Information Technology Management, IEEE, Information and Management, which were not included in this study. These journals have their own rules and themes in selecting topics and methodologies; hence, the results of this study could be generalized to all the research information management systems with little caution.

Another limitation is concerned with the classification scheme for the research topics. Despite the fact that a highly comprehensive list of topics was developed based on the previous research, the topic list turned out not to be completely comprehensive, and the topics of some papers were not included in these categories. Accordingly, some of the issues were inevitably added during the coding process. The same limitation was noticed regarding the research methodology. One more limitation was the level of details for the topics. In order to preserve meaningfulness, topic categories should not be too broad or too limited. In this regard, we were to have an appropriate level of topic classification, to the best knowledge of the research team. However, the findings were at the same time affected by the type of thematic categories to some extent. In other words, the categories were affected by the topics grouped together or separated from each other. For example, a team, a virtual team, and collaboration were grouped together in one category; however, social networks and social media were classified separately. This came true for the level of methodological details.

Finally, since coding a large number of papers requires the division of tasks, and coding was carried out by three coders, there may be differences in codes. We spared our efforts to minimize such concerns through evaluating the coders using two sets of papers and reaching a common understanding. Moreover, the inter-coder reliability was higher than the recommended values, indicating that there was a considerable degree of common understanding and agreement among the coders.

Considering the scope of the research, future researchers are recommended to consider other journals and compare them with the findings of the present research. Furthermore, more comprehensive frameworks are suggested to be considered for future work. In other words, in addition to topics and methodologies, the future studies should include models and approaches, paradigms, writers, and universities. Further, the future researchers can examine the adopted research methodologies to determine which methodology and topic are more consistent. 


\section{References}

Alavi, M., \& Carlson, P. (1992). A review of MIS research and disciplinary development. Journal of Management Information Systems, 8(4), 45-62.

Avison, D. E., Dwivedi, Y. K., Fitzgerald, G., \& Powell, P. (2008). The beginnings of a new era: time to reflect on 17 years of the ISJ. Information Systems Journal, 18(1), 5-21.

Barki, H., Rivard, S., \& Talbot, J. (1988). An information systems keyword classification scheme. MIS quarterly, 299-322.

Barki, H., Rivard, S., \& Talbot, J. (1993). A keyword classification scheme for IS research literature: an update. MIS quarterly, 209-226.

Chen, W., \& Hirschheim, R. (2004). A paradigmatic and methodological examination of information systems research from 1991 to 2001. Information Systems Journal, 14(3), 197235.

Claver, E., González, R., \& Llopis, J. (2000). An analysis of research in information systems (1981-1997). Information \& Management, 37(4), 181-195.

Cumbie, B. A., Jourdan, Z., Peachey, T., Dugo, T. M., \& Craighead, C. W. (2005). Enterprise resource planning research: where are we now and where should we go from here? JITTA: Journal of Information Technology Theory and Application, 7(2), 21.

D'Aubeterre, F., Palvia, P., \& Steevens, J. (2005). A meta-analysis of current global information systems research. AMCIS 2005 Proceedings, 48.

Davis, F. D. (1989). Perceived usefulness, perceived ease of use, and user acceptance of information technology. MIS quarterly, 319-340.

Dwivedi, Y. K., \& Kuljis, J. (2008). Profile of IS research published in the European Journal of Information Systems. European Journal of Information Systems, 17(6), 678-693.

Farhoomand, A., \& Drury, D. H. (1999). A historiographical examination of information systems. Communications of the AIS, 1(5es), 4.

Feldman, R., \& Sanger, J. (2007). The text mining handbook: advanced approaches in analyzing unstructured data: Cambridge university press.

Fuller, C. M., Biros, D. P., \& Delen, D. (2011). An investigation of data and text mining methods for real world deception detection. Expert Systems with Applications, 38(7), 8392-8398.

The International Conference on Information Systems. Retrieved 12/15/2019, from https://icis2020.aisconferences.org/track-descriptions/

Ji, S., Min, Q., \& Han, W. (2004). Overview of information systems research in China: An empirical study. PACIS 2004 Proceedings, 13.

Levy, Y., \& Ellis, T. J. (2006). A systems approach to conduct an effective literature review in support of information systems research. Informing Science, 9.

Liu, F., \& Myers, M. D. (2011). An analysis of the AIS basket of top journals. Journal of Systems and Information Technology, 13(1), 5-24.

Milne, M. J., \& Adler, R. W. (1999). Exploring the reliability of social and environmental disclosures content analysis. Accounting, Auditing \& Accountability Journal, 12(2), 237-256. 
Myers, M., \& Liu, F. (2009). What does the best is research look like? An analysis of the ais basket of top journals. PACIS 2009 Proceedings, 61.

Neuman, W. (2003). Social research methods: Qualitative and quantitative approaches . Boston, MA: Allyn \& Bacon.

Pacific Asia Conference on Information Systems. Retrieved 12/15/2019, from https://www.pacis2020.org/conference-tracks/

Palvia, P., \& Kakhki, M. D. (2016). Methodological and topic trends in JGITM: A 10-Year retrospect: Taylor \& Francis.

Palvia, P., Kakhki, M. D., Ghoshal, T., Uppala, V., \& Wang, W. (2015). Methodological and Topic Trends in Information Systems Research: A Meta-Analysis of IS Journals. CAIS, 37,30 .

Palvia, P., Leary, D., Mao, E., Midha, V., Pinjani, P., \& Salam, A. (2004). Research methodologies in MIS: an update. Communications of the Association for Information Systems, 14(1), 24.

Palvia, P., Mao, E., Salam, A., \& Soliman, K. S. (2003). Management information systems research: what's there in a methodology? Communications of the Association for Information Systems, 11(1), 16 .

Palvia, P., Pinjani, P., \& Sibley, E. H. (2007). A profile of information systems research published in Information \& Management. Information \& Management, 44(1), 1-11.

Palvia, P., YK, C. P., Kakhki, M. D., Ghoshal, T., Uppala, V., \& Wang, W. (2017). A decade plus long introspection of research published in Information \& Management. Information $\mathcal{E}$ Management, 54(2), 218-227.

Scimago Journal \& Country Rank. Retrieved 12/15/2019, from https://www.scimagojr.com/journalrank.php

Sinclaire, J., Simon, J., \& Wilkes, R. (2004). Research Directions in MIS: An Assessment of Current Status. AMCIS 2004 Proceedings, 529.

Stemler, S. (2001). An overview of content analysis. Practical assessment, research \& evaluation, 7(17), 137-146.

Tan, A.-H. (1999). Text mining: The state of the art and the challenges. Paper presented at the Proceedings of the PAKDD 1999 Workshop on Knowledge Disocovery from Advanced Databases.

Weber, R. (1988). Basic content analysis, Sage University paper series on quantitative applications. The Social Science, Series(07-049).

Webster, J., \& Watson, R. T. (2002). Analyzing the past to prepare for the future: Writing a literature review. MIS Quarterly, xiii-xxiii.

Copyright: (c) 2020 Mazaheri, Lagzian \& Hemmat. This is an open-access article distributed under the terms of the Creative Commons Attribution-NonCommercial 3.0 Australia License, 
which permits non-commercial use, distribution, and reproduction in any medium, provided the original author and AJIS are credited.

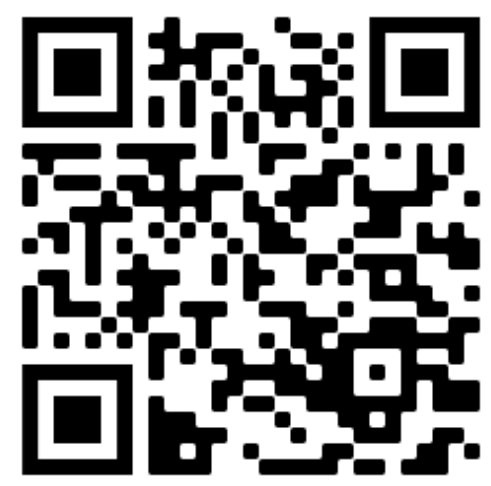

